\title{
Evaluation of Endophytic Bacterial Isolates against Root Knot Nematode, Meloidogyne incognita in Tomato under Glasshouse Condition
}

\author{
P. Vetrivelkalai* \\ Department of Fruit Crops, Tamil Nadu Agricultural University, Coimbatore - 641 003, \\ Tamil Nadu, India \\ *Corresponding author
}

\section{A B S T R A C T}

\section{Ke y w o r d s \\ Endophytic \\ bacterial isolates, \\ Plant Growth \\ Promotion, \\ Biocontrol \\ potential, Tomato \\ and Meloidogyne \\ incognita}

Article Info

Accepted:

17 December 2018

Available Online:

10 January 2019
Eight endophytic Pseudomonas sp. isolates viz., EB1 to EB8 and ten endophytic Bacillus sp. isolates viz., EB9 to EB18 and one endophytic Methylobacterium sp. isolate EB19 were tested their plant growth promotion activity and biocontrol potential against root knot nematode, Meloidogyne incognita in tomato. On seed bacterization with nineteen endophytic bacterial isolates, eight isolates viz., EB19, EB16, EB18, EB3, EB11, EB2, EB10 and EB6 significantly enhanced the germination percentage, shoot and root length and vigour index of tomato seedlings by roll towel technique and pot culture studies. The promising eight endophytic bacterial isolates were screened for their nematicidal action against Meloidogye incognita in tomato under pot culture conditions. The study revealed that the culture filtrates of endophytic Bacillus sp. isolates viz., EB16, EB18, Methylobacterium sp. EB19 and Pseudomonas sp. EB3 significantly reduced the number of adult females, egg masses, eggs/eggmass, soil and root population of $M$. incognita. The lowest root gall index (1.33) was registered both in EB16 and EB18 isolates and it was followed by EB19 and EB3 (1.67) compared to untreated control (4.67).

\section{Introduction}

Tomato (Lycopersicon esculentum Mill.) is the world's largest and important commercial vegetable grown in tropical and subtropical areas for its fleshy fruits. The southern root knot nematode, Meloidogyne incognita is one of the major constraints in the production of tomato in tropical and subtropical regions. In India, the annual losses caused by root knot nematode, $M$. incognita is 27.2 per cent in tomato (Jain et al., 2007). Present strategies for nematode management largely depend on cultural practices such as crop rotations are widely used but not effective when adopted individually. The use of resistant varieties for commercial purpose has limited scope due to lack of resistance genes in cultivable crops. Only few nematicides are available to the growers in the Indian market for the management of nematodes. The chemical residual effects are reflected in the food chain which are hazardous to health and they pollute the environment with disturbance in 
agro-ecosystems. In order to overcome these drawbacks, use of environment friendly, beneficial natural antagonists would serve as an economic and effective alternative method for management of phytonematodes.

The endophytic microorganisms colonizing plant root tissues may be able to manage endoparsitic nematodes due to the fact that both of them occupy the same ecological niche and are in close contact. In mutualistic associations, endophyte colonized plants are protected from pathogen attack and host plant in turn provides shelter and nutrition to the endophytes. Hence, an attempt was made to analysis of plant growth promotion activity and biocontrol potential of endophytes against M. incognita in tomato.

\section{Materials and Methods}

\section{Endophytic bacterial culture filtrate}

The endophytic bacterial isolates were grown in their respective medium for 3-4 days. The liquid culture was filtered through Whatman No.1 filter paper and passed through bacterial filter. Filtrates were centrifuged at $6000 \mathrm{rpm}$ for $15 \mathrm{~min}$. The supernatant was taken and the suspended residue was discarded.

\section{Plant growth promotion activity}

To test the germination percentage and vigour index, seed bacterization was done for the isolated endophytic bacterial strains and a standard Pf1 strain which was obtained from Department of Plant Pathology, Tamil Nadu Agricultural University, Coimbatore, India. Tomato seeds were surface sterilized with 0.1 per cent mercuric chloride for two minutes and washed with distilled water, then seeds were soaked with culture filtrate (100\%) for $3 \mathrm{hr}$. The bacterial treated tomato seeds were assessed by modified roll towel method as well as pot culture conditions. The germination percentage, shoot length and root length were recorded at 14 and 25 days after germination of tomato seeds by roll towel and pot culture studies, respectively. The Vigour index (VI) was calculated using following formula (Abdul Baki and Anderson, 1973) as $\mathrm{VI}=$ Germination percentage $\mathrm{X}$ Seedling length (shoot length + root length)

\section{Nematicidal efficacy}

Tomato seeds were surface sterilized with 0.1 per cent mercuric chloride for two minutes and washed with distilled water, then seeds were soaked with culture filtrate $(100 \%)$ for $3 \mathrm{hr}$. Treated seeds were sown in autoclaved pot mixture in earthern pots.

After 25 days after, the seedlings were transplanted in $5 \mathrm{~kg}$ earthern pots at one seedling per pot. $10 \mathrm{ml}$ of culture filtrate of bacterial isolates was poured at 15 days after transplanting in the rhizosphere zone and covered with pot mixture. Freshly hatched $5000 \mathrm{~J}_{2}$ of $M$. incognita was inoculated per pot. After 30 days after inoculation, final nematode population in soil, number of adult females, number of egg masses, number of eggs/egg mass and root population were observed. The collected soil samples were processed by Cobb's sieving and decanting method (Cobb, 1918) and Modified Baermann funnel technique (Schindler, 1961) to assess the population of root knot nematode infesting tomato.

The representative $5 \mathrm{~g}$ root samples of each pot were washed free of soil and stained with $0.1 \%$ acid fuchsin in lactophenol solution to examine the gall index, number of females, egg masses and eggs/eggmass per $5 \mathrm{~g}$ root. The gall index was graded with 1 to 5 scale rating (Headle et al., 1989). All the data were statically analyzed and critical difference determined. 


\section{Results and Discussion}

\section{Plant growth promotion activity}

The results revealed that, the highest germination percentage $(83 \%)$ was recorded with the isolates EB19 followed by EB16, EB18, EB3, EB11, EB2, EB10 and EB6 with 80.0, 77.0, 73.67, 71.0, 68.33, 66.0 and 63.0 per cent, respectively. The highest shoot length and root length was recorded in tomato treated with the isolates EB19, EB16, EB18, EB3, EB11, EB2, EB10 and EB6 with value of $7.13,6.57,6.07,5.5,5.5,5.2,4.77,4.63 \mathrm{~cm}$ and 12.27, 11.83, 11.40, 11.07, 10.50, 10.17, $9.9,9.53 \mathrm{~cm}$, respectively. The highest vigour index was observed in tomato seeds treated with the isolates EB19, EB16, EB18, EB3, EB11, EB2, EB10 and EB6 with an index of $1610.60,1470.37,1344.80,1220.13,1136.20$, $1050.33,972.37$ and 892.57 , respectively by roll towel method (Table 1).

The endophytic bacterial isolates viz., EB19, EB16, EB18, EB3, EB11, EB2, EB10 and EB6 recorded highest germination percentage in tomato with $83.33,82.00,80.6779 .00$, 78.0, 77.0, 75.33 and 73.67, respectively. Shoot length and root length of tomato were increased by endophytic bacterial isolates viz., EB19, EB16, EB18, EB3, EB11, EB2, EB10 and EB6 with values of 28.93, 27.27, 25.70, $23.53,21.83,20.50,19.37$ and $18.50 \mathrm{~cm}$ and $22.03,21.53,20.73,20,18.77,17.60,16.53$ and $15.23 \mathrm{~cm}$ respectively. The highest vigour index was recorded in EB19 treated tomato seeds 4243 followed by EB16, EB18, EB3, EB11, EB2, EB10 and EB6 recorded in tomato with $4002.33,3747.27,3438.97$, $3165.73,2931.13,705.73$ and 2485.90 under pot culture studies.

Similarly, several reports have indicated that bacterial endophytes promote the growth of tomato (Munif et al., 2013). The endophytic bacteria may promote plant growth and suppress plant diseases probably by means similar to plant growth promoting rhizobacteria. The mechanisms by which plant growth is improved may be similar to those exhibited by rhizosphere microorganisms and include the production of phytohormones, promotion through enhanced availability of nutrients, reduction of ethylene levels, production of antibiotics and induced systemic resistance (Holland, 1997). The present results were also in conformity with the earlier reports.

\section{Effect of culture filtrate on $M$. incognita}

The best performing eight bacterial isolates were screened for their nematicidal action against root knot nematode, $M$. incognita in tomato based on the results of growth promotion activities. The culture filtrates of EB19, EB18, EB16 and EB3 significantly reduced the number of adult females, egg masses, eggs/eggmass, root and soil population of $M$. incognita under pot culture conditions (Table 2).

The significant reduction in the number of adult females (31.33) was observed in tomato plants treated with culture filtrate of EB16 isolate, which accounts for 72.02 per cent over control. It was followed by EB18 (40.33), EB19 (49.67) and EB3 (55.33). The lowest number of egg masses and eggs/ eggmass was observed in EB16 treated plants which accounted for 15.67 and 102.67, respectively followed by EB18, EB19 and EB3.The highest number of egg masses (68.33) and eggs/ eggmass (265.67) was recorded in control.

The reduction in soil and root population was observed in EB16 treated plants by 64.03 and 68.52 per cent respectively followed by EB18, EB19 and EB3 which accounted for 58.96, 54.55, 47.40 and 63.20, 56.90, 50.61 per cent reduction over control, respectively. 
The highest nematode population in soil (256.67) and root (137.67) was observed in control. The lowest root gall index (1.33) was registered both in EB16 and EB18 treated tomato plants and it was followed by EB19 and EB3 (1.67) compared to untreated control (4.67).

Similar results were obtained by Jonathan and Umamaheswari (2006), Vetrivelkalai et al., (2010) who reported that gall index, egg mass production, eggs/egg mass and soil nematode population were significantly reduced in plants treated with culture filtrates of Pseudomonas and Bacillus. The four selected endophytic bacteria viz., Pantoea agglomerans MK-29, Cedecea davisae MK30, Enterobacter spp. MK-42 and Pseudomonas putida MT-19 also significantly reduced early root penetration of Meloidogyne juveniles into tomato roots upto $56 \%$, when applied as a root dipping and soil drench (Munif et al., 2013). Siddiqui and Shaukat (2003) also found that aqueous cell suspension of $P$. fluorescens strains CHA0 or $\mathrm{CHA} 0 / \mathrm{pME} 3424$ at various inoculum levels $10^{7}, 10^{8}, 10^{9} \mathrm{cfu} / \mathrm{g}$ significantly reduced root knot development in tomato under glasshouse conditions.

Table.1 Plant growth promotion activity of endophytic bacterial isolates in tomato

\begin{tabular}{|c|c|c|c|c|c|c|c|c|c|}
\hline \multirow[t]{2}{*}{$\begin{array}{l}\text { S. } \\
\text { No. }\end{array}$} & \multirow[t]{2}{*}{ Isolates } & \multicolumn{2}{|c|}{$\begin{array}{c}\text { Germination } \\
(\%)\end{array}$} & \multicolumn{2}{|c|}{$\begin{array}{l}\text { Shoot length } \\
(\mathrm{cm})\end{array}$} & \multicolumn{2}{|c|}{ Root length $(\mathrm{cm})$} & \multicolumn{2}{|c|}{ Vigour index } \\
\hline & & Roll & Pot & Roll & Pot & Roll & Pot & Roll & Pot \\
\hline 1 & EB 1 & $36.00^{\mathrm{lm}}$ & $50.00^{j}$ & $4.07^{\text {hi }}$ & $13.37^{\mathrm{k}}$ & $8.30^{\mathrm{ij}}$ & $10.10^{\mathrm{kl}}$ & $445.80^{\mathrm{mn}}$ & $1171.73^{\mathrm{m}}$ \\
\hline 2 & EB 2 & $68.33^{\text {ef }}$ & $77.00^{\text {de }}$ & $5.20^{\mathrm{de}}$ & $20.50^{\text {ef }}$ & $10.17^{\mathrm{ef}}$ & $17.60^{\text {de }}$ & $1050.33^{f}$ & $2931.13^{f}$ \\
\hline 3 & EB 3 & $73.67^{\mathrm{cd}}$ & $79.00^{\mathrm{bc}}$ & $5.50^{\mathrm{cd}}$ & $23.53^{d}$ & $11.07^{\mathrm{cd}}$ & $20.00^{\mathrm{bc}}$ & $1220.13^{d}$ & $3438.97^{d}$ \\
\hline 4 & EB 4 & $53.67^{\mathrm{i}}$ & $66.00^{\mathrm{g}}$ & $4.53^{\mathrm{fg}}$ & $17.63^{\mathrm{hi}}$ & $9.17^{\mathrm{gh}}$ & $13.23^{\mathrm{hi}}$ & $735.37^{\mathrm{j}}$ & $2035.80^{j}$ \\
\hline 5 & EB 5 & $48.67^{\mathrm{j}}$ & $61.33^{\mathrm{h}}$ & $4.53^{\mathrm{fg}}$ & $17.13^{\mathrm{hi}}$ & $8.90^{\mathrm{hi}}$ & $12.50^{\mathrm{ij}}$ & $653.90^{\mathrm{k}}$ & $1819.00^{k}$ \\
\hline 6 & EB 6 & $63.00^{\mathrm{gh}}$ & $73.67^{\mathrm{ef}}$ & $4.63^{\mathrm{fg}}$ & $18.50^{\mathrm{gh}}$ & $9.53^{\mathrm{fg}}$ & $15.23^{\mathrm{fg}}$ & $892.57^{\mathrm{h}}$ & $2485.90^{h}$ \\
\hline 7 & EB 7 & $44.33^{k}$ & $57.00^{\mathrm{i}}$ & $4.17^{\mathrm{hi}}$ & $16.50^{\mathrm{i}}$ & $8.83^{\text {hi }}$ & $11.57^{\mathrm{jk}}$ & $575.93^{1}$ & $1596.53^{1}$ \\
\hline 8 & EB 8 & $34.67^{\mathrm{mn}}$ & $42.33^{\mathrm{k}}$ & $3.73^{\mathrm{ij}}$ & $12.73^{\mathrm{kl}}$ & $8.33^{\mathrm{ij}}$ & $9.90^{\mathrm{mn}}$ & $420.50^{n}$ & $958.23^{\text {no }}$ \\
\hline 9 & EB 9 & $31.67^{\text {no }}$ & $41.67^{\mathrm{kl}}$ & $3.80^{\mathrm{ij}}$ & $11.17^{\mathrm{mn}}$ & $8.70^{\mathrm{ij}}$ & $8.33^{\mathrm{op}}$ & $395.73^{n}$ & $812.50^{p}$ \\
\hline 10 & EB 10 & $66.00^{\mathrm{fg}}$ & $75.33^{\text {de }}$ & $4.77^{\text {ef }}$ & $19.37^{\mathrm{g}}$ & $9.97^{\text {ef }}$ & $16.53^{\mathrm{ef}}$ & $972.37^{\mathrm{g}}$ & $2705.73^{\mathrm{g}}$ \\
\hline 11 & EB 11 & $71.00^{\mathrm{de}}$ & $78.00^{\mathrm{cd}}$ & $5.50^{\mathrm{cd}}$ & $21.83^{\mathrm{e}}$ & $10.50^{\mathrm{de}}$ & $18.77^{\mathrm{ed}}$ & $1136.20^{\mathrm{e}}$ & $3165.73^{e}$ \\
\hline 12 & EB 12 & $38.67^{1}$ & $54.67^{i}$ & $4.33^{\text {gh }}$ & $15.03^{j}$ & $8.60^{\mathrm{ij}}$ & $11.27^{\mathrm{kl}}$ & $500.27^{1 \mathrm{~m}}$ & $1438.57^{1}$ \\
\hline 13 & EB 13 & $27.00^{\mathrm{p}}$ & $49.33^{j}$ & $3.37^{j}$ & $10.40^{\mathrm{mn}}$ & $7.10^{\mathrm{jk}}$ & $8.73^{\mathrm{op}}$ & $280.93^{p}$ & $945.47^{\text {no }}$ \\
\hline 14 & EB 14 & $32.33^{\mathrm{no}}$ & $39.33^{\mathrm{kl}}$ & $3.60^{\mathrm{ij}}$ & $10.90^{\mathrm{mn}}$ & $8.07^{j}$ & $7.80^{\mathrm{np}}$ & $377.00^{\text {no }}$ & $735.80^{p}$ \\
\hline 15 & EB 15 & $29.67^{\mathrm{op}}$ & $37.67^{1}$ & $3.40^{j}$ & $9.73^{n}$ & $7.20^{\mathrm{k}}$ & $8.37^{\mathrm{op}}$ & $315.33^{\mathrm{op}}$ & $678.43^{p}$ \\
\hline 16 & EB 16 & $80.00^{\mathrm{ab}}$ & $82.00^{\mathrm{ab}}$ & $6.57^{\mathrm{ab}}$ & $27.27^{b}$ & $11.83^{\mathrm{ab}}$ & $21.53^{\mathrm{a}}$ & $1470.37^{b}$ & $4002.33^{b}$ \\
\hline 17 & EB 17 & $34.00^{\mathrm{mn}}$ & $40.33^{\mathrm{kl}}$ & $3.90^{\mathrm{ij}}$ & $11.63^{\operatorname{lm}}$ & $7.97^{\mathrm{j}}$ & $9.60^{\text {no }}$ & $401.43^{n}$ & $858.37^{\text {noq }}$ \\
\hline 18 & EB 18 & $77.00^{\mathrm{bc}}$ & $80.67^{\mathrm{bc}}$ & $6.07^{b c}$ & $25.70^{c}$ & $11.40^{\mathrm{bc}}$ & $20.73^{\mathrm{ab}}$ & $1344.80^{c}$ & $3747.27^{\mathrm{c}}$ \\
\hline 19 & EB 19 & $83.00^{\mathrm{a}}$ & $83.33^{\mathrm{a}}$ & $7.13^{\mathrm{a}}$ & $28.93^{a}$ & $12.27^{\mathrm{a}}$ & $22.03^{\mathrm{ab}}$ & $1610.60^{\mathrm{a}}$ & $4243.00^{a}$ \\
\hline 20 & Pf 1 & $59.00^{\mathrm{h}}$ & $70.67^{f}$ & $4.60^{\text {gh }}$ & $18.00^{\mathrm{gh}}$ & $9.20^{\mathrm{h}}$ & $14.13^{\mathrm{gh}}$ & $814.60^{\mathrm{i}}$ & $2270.67^{i}$ \\
\hline \multirow[t]{3}{*}{21} & Control & $46.00^{\mathrm{k}}$ & $46.67^{j}$ & $4.07^{i}$ & $12.67^{\mathrm{kl}}$ & $8.37^{\mathrm{ij}}$ & $9.67^{\mathrm{no}}$ & $572.73^{1}$ & $1042.23^{\mathrm{mr}}$ \\
\hline & S Ed & 2.04 & 1.99 & 0.29 & 0.71 & 0.37 & 0.77 & 37.54 & 91.23 \\
\hline & $\begin{array}{l}\text { CD } \\
(P=0.01)\end{array}$ & 5.53 & 5.26 & 0.79 & 2.08 & 1.01 & 1.76 & 101.52 & 212.18 \\
\hline
\end{tabular}

* Values are mean of three replications

In column means followed by a common letter are not significant at 1 per cent level by DMRT 
Table.2 Effect of culture filtrate of endophytic bacterial isolates against $M$. incognita in tomato (Mean of three replications)

\begin{tabular}{|c|c|c|c|c|c|c|c|}
\hline S.No. & Isolates & $\begin{array}{c}\text { No. of } \\
\text { females } \\
(5 g \\
\text { root })\end{array}$ & $\begin{array}{l}\text { No. egg } \\
\text { masses } \\
\text { (5g root) }\end{array}$ & $\begin{array}{l}\text { No. of } \\
\text { eggs/ egg } \\
\text { mass }\end{array}$ & $\begin{array}{l}\text { Root } \\
\text { knot } \\
\text { index }\end{array}$ & $\begin{array}{l}\text { Soil } \\
\text { population } \\
\text { (250cc soil) }\end{array}$ & $\begin{array}{l}\text { Root } \\
\text { population } \\
\text { (5g root) }\end{array}$ \\
\hline 1 & EB 2 & $\begin{array}{c}76.67^{\mathrm{g}} \\
(31.55)\end{array}$ & $\begin{array}{l}42.00^{g} \\
(38.54)\end{array}$ & $\begin{array}{l}159.00^{\mathrm{g}} \\
(40.15)\end{array}$ & 2.33 & $\begin{array}{l}183.67^{\mathrm{g}} \\
(28.44)\end{array}$ & $\begin{array}{c}98.67^{g} \\
(28.33)\end{array}$ \\
\hline 2 & EB 3 & $\begin{array}{l}55.33^{d} \\
(50.60)\end{array}$ & $\begin{array}{l}29.00^{d} \\
(57.56)\end{array}$ & $\begin{array}{l}128.33^{d} \\
(51.69)\end{array}$ & 1.67 & $\begin{array}{l}135.00^{d} \\
(47.40)\end{array}$ & $\begin{array}{c}68.00^{d} \\
(50.61)\end{array}$ \\
\hline 3 & EB 6 & $\begin{array}{c}88.00^{i} \\
(21.43)\end{array}$ & $\begin{array}{c}50.67^{i} \\
(25.85)\end{array}$ & $\begin{array}{l}202.33^{i} \\
(23.84)\end{array}$ & 3.00 & $\begin{array}{l}219.67^{i} \\
(14.42)\end{array}$ & $\begin{array}{l}115.00^{i} \\
(16.46)\end{array}$ \\
\hline 4 & EB 10 & $\begin{array}{l}82.67^{\mathrm{h}} \\
(26.19)\end{array}$ & $\begin{array}{l}46.33^{\mathrm{h}} \\
(32.20)\end{array}$ & $\begin{array}{l}176.33^{h} \\
(33.63)\end{array}$ & 3.33 & $\begin{array}{l}207.33^{h} \\
(19.22)\end{array}$ & $\begin{array}{l}107.33^{h} \\
(22.03)\end{array}$ \\
\hline 5 & EB 11 & $\begin{array}{c}68.33^{f} \\
(38.99)\end{array}$ & $\begin{array}{c}37.67^{f} \\
(44.88)\end{array}$ & $\begin{array}{l}144.33^{f} \\
(45.67)\end{array}$ & 2.33 & $\begin{array}{l}172.33^{f} \\
(32.86)\end{array}$ & $\begin{array}{c}88.67^{f} \\
(35.59)\end{array}$ \\
\hline 6 & EB 16 & $\begin{array}{c}31.33^{\mathrm{a}} \\
(72.02)\end{array}$ & $\begin{array}{c}15.67^{\mathrm{a}} \\
(77.07)\end{array}$ & $\begin{array}{l}102.67^{a} \\
(61.36)\end{array}$ & 1.33 & $\begin{array}{c}92.33^{\mathrm{a}} \\
(64.03)\end{array}$ & $\begin{array}{c}43.33^{a} \\
(68.52)\end{array}$ \\
\hline 7 & EB 18 & $\begin{array}{l}40.33^{b} \\
(63.99)\end{array}$ & $\begin{array}{c}20.00^{b} \\
(70.73)\end{array}$ & $\begin{array}{l}112.00^{b} \\
(57.84)\end{array}$ & 1.33 & $\begin{array}{l}105.33^{b} \\
(58.96)\end{array}$ & $\begin{array}{c}50.67^{b} \\
(63.20)\end{array}$ \\
\hline 8 & EB 19 & $\begin{array}{l}49.67^{\mathrm{c}} \\
(55.65)\end{array}$ & $\begin{array}{l}24.67^{c} \\
(63.90)\end{array}$ & $\begin{array}{l}120.33^{c} \\
(54.71)\end{array}$ & 1.67 & $\begin{array}{l}116.67^{c} \\
(54.55)\end{array}$ & $\begin{array}{c}59.33^{c} \\
(56.90)\end{array}$ \\
\hline 9 & Pf 1 & $\begin{array}{l}61.33^{\mathrm{e}} \\
(45.24)\end{array}$ & $\begin{array}{c}33.33^{\mathrm{e}} \\
(51.22)\end{array}$ & $\begin{array}{l}136.33^{\mathrm{e}} \\
(48.68)\end{array}$ & 1.67 & $\begin{array}{l}145.00^{\mathrm{e}} \\
(43.51)\end{array}$ & $\begin{array}{c}79.00^{\mathrm{e}} \\
(42.62)\end{array}$ \\
\hline \multirow[t]{3}{*}{10} & Control & $112.00^{\mathrm{j}}$ & $68.33^{j}$ & $265.67^{j}$ & 4.67 & $256.67^{j}$ & $137.67^{j}$ \\
\hline & $\mathrm{S} \mathrm{Ed}$ & 2.09 & 2.00 & 3.69 & - & 3.13 & 2.53 \\
\hline & $\begin{array}{l}\text { CD } \\
(P=0.05)\end{array}$ & 4.36 & 4.18 & 7.68 & - & 6.54 & 5.28 \\
\hline
\end{tabular}

In column means followed by a different letters are significantly from each other at 5 per cent level by DMRT Figures in parentheses are per cent reduction over control

The mechanisms by which reduction on nematode population might be due to competition for space and nutrients; premature egg hatching and reduction in viability and mortality of juveniles induced by secondary metabolites such as 2,4 DAPG and lytic enzymes (Dunne et al., 1998) antibiotics and hydrogen cyanide produced by Pseudomonas spp. and non cellular extract and toxic metabolites like bacillopeptidase, subtillin $\mathrm{E}$ and $\beta$ lactamase from Bacillus spp. Methylobacterium spp. produced indole acetic acid able to utilize ACC deaminase as sole carbon source, which regulates ethylene production by metabolizing ACC into $\alpha$ ketobutyrate and ammonia (Glick et al., 1998) and this ammonia is toxic to nematodes. Hence, the promising endophytic bacterial isolates obtained from the present study may be mass multiplied in a suitable media and developed commercial formulation for the management of $M$. incognita in tomato.

\section{References}

Abdul Baki, A.A and Anderson, J.D. 1973. Vigour determination in soybean seed by multiple criteria. Crop Sciences, 
31: 630-633.

Cobb, N.A. 1918. Estimating the nematode population of soil. United States Department of Agriculture, Circular No. 1, 48pp.

Dunne, C., Moenne-Loccoz, Y., Mc Carthy, J., Higgins, P., Powell, J., Dowing, D.N., and Gara, F.O. 1998. Combining proteolytic and phloroglucinol-producing bacteria for improved biocontrol of Pythiummediated damping off of sugarbeet. Plant Pathology, 47: 299-307.

Glick, B.R., Penrose, D.M., and Li, J., 1998. A model for the lowering of plant ethylene concentrations by plant growth-promoting bacteria. Journal of Theoretical Biology, 190: 63-68.

Headle, C.M., Briton, B.D., and Davis, R.M. 1989. Influence of Glomus intradices and soil phosphorus on Meloidogyne incognita infecting Cucumis melo. Journal of Nematology, 21: 69-73.

Holland, M.A. 1997. CAM's razor applied to hormonology: Are cytokinnins produced by plants. Plant Physiology, 115: 865-868.
2007. Estimation of losses due to plant parasitic nematodes on different crops in India. Indian Journal of Nematology, 37: 219-221.

Jonathan, E.I. and Umamaheswari, R. 2006. Biomanagement of nematodes infesting banana by bacterial endophytes (Bacillus subtilis). Indian Journal of Nematology, 36: 30-233.

Munif A., Hallmann, J., and Sikora, R.A. 2013. The influence of endophytic bacteria on Meloidogyne incognita infection and tomato plant growth. Journal of International Society for Southeast Asian Agricultural Sciences, 19: 68-74.

Schindler, A. F. 1961. A simple substitute for a Baermann funnel. Plant Disease Report, 45: 747-748.

Siddiqui, I.A. and Shaukat, S.S. 2003. Suppression of root knot disease by Pseudomonas fluorescens CHA0 in tomato: importance of bacterial secondary metabolite, 2,4diacetylphologlucinol. Soil Biology and Biochemistry, 35: 1615-1623.

Jain, R.K., Mathur, K.N., and Singh, R.V.

\section{How to cite this article:}

Vetrivelkalai, P. 2019. Evaluation of Endophytic Bacterial Isolates against Root Knot Nematode, Meloidogyne incognita in Tomato under Glasshouse Condition. Int.J.Curr.Microbiol.App.Sci. 8 (01): 2584-2589. doi: https://doi.org/10.20546/ijcmas.2019.801.271 